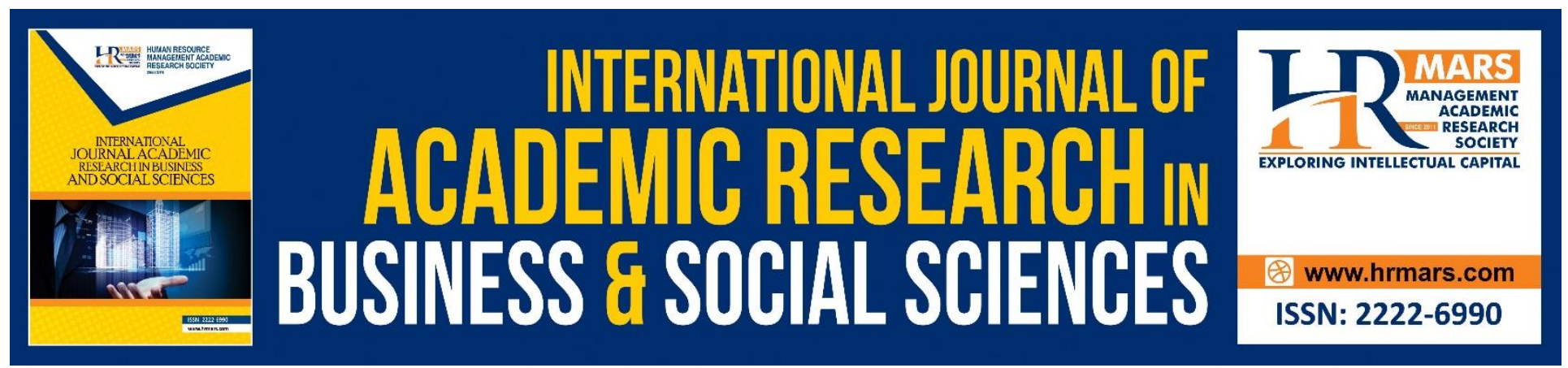

\title{
Paradox of Quality Assurance in the Management and Administration of University Education in Nigeria: National Universities' Commission (NUC) in Focus
}

Paulley, F. Godgift

To Link this Article: http://dx.doi.org/10.6007/IJARBSS/v9-i3/5637

DOI: $\quad 10.6007 /$ IJARBSS/v9-i3/5637

Received: 08 Feb 2019, Revised: 13 March 2019, Accepted: 21 March 2019

Published Online: 02 April 2019

In-Text Citation: (Paulley, 2019)

To Cite this Article: Paulley, F. G. (2019). Paradox of Quality Assurance in the Management and Administration of University Education in Nigeria: National Universities' Commission (NUC) in Focus. International Journal of Academic Research in Business and Social Sciences, 9(3), 113-131.

Copyright: (C) 2019 The Author(s)

Published by Human Resource Management Academic Research Society (www.hrmars.com)

This article is published under the Creative Commons Attribution (CC BY 4.0) license. Anyone may reproduce, distribute, translate and create derivative works of this article (for both commercial and non-commercial purposes), subject to full attribution to the original publication and authors. The full terms of this license may be seen at: http://creativecommons.org/licences/by/4.0/legalcode

Vol. 9, No. 3, 2019, Pg. 113 - 131

http://hrmars.com/index.php/pages/detail/IJARBSS

JOURNAL HOMEPAGE

Full Terms \& Conditions of access and use can be found at http://hrmars.com/index.php/pages/detail/publication-ethics 


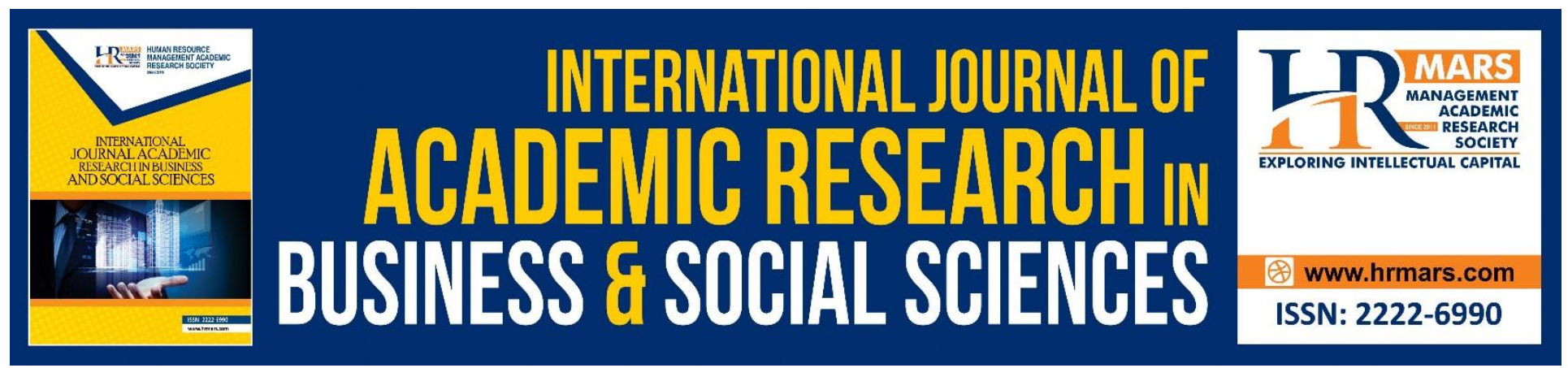

\title{
Paradox of Quality Assurance in the Management and Administration of University Education in Nigeria: National Universities' Commission (NUC) in Focus
}

\author{
Paulley, F. Godgift \\ Department of Educational Foundations, Faculty of Education, Niger Delta University, \\ Wilberforce Island, Bayelsa State \\ Email: paulleyfg@mail.ndu.edu.ng
}

\begin{abstract}
The historical method of data collection, analysis and discussion was used to study and report on the role of the National Universities' Commission (NUC), an agency set up by the Federal Government for all universities, irrespective of ownership (federal, state or private) in ascertaining quality assurance in the management and administration of university education in Nigeria with reference to setting up of minimum academic standard for all academic programmes. The objective was to determine the level of effectiveness of the supervisory/regulatory role(s) of the commission and highlight the local factors that have militated against the attainment of quality assurance in universities in Nigeria. It was found that while the concern for quality assurance in Nigerian university education as pursued by the NUC is commendable and most desirable, the paradox, however, is that the same government is not funding university education adequately. On the basis of these findings, it was suggested that the funding of university education in the country should be a priority as prescribed by UNESCO, since the country is a signatory to the UNO charter so that the needed standard could be met.
\end{abstract}

Introduction

The training and production of the right mix and quantity of high-level manpower from the educational system is considered sine qua non for national development. These precisely are the goals of tertiary institutions in all countries.

This the universities do through the basic functions of teaching and imparting knowledge, seeking and discovering truth through research and disseminating their findings to all so that mankind generally may shed the shackles of ignorance and want. In other words, the graduates of tertiary institutions, as represented by the universities in this work, are meant to play a major role in teaching, research and development, curriculum development, quality control, evaluation, management of 
both private and public enterprises, improved food supply, health delivery, politics and governance, maintenance of law and order and other community services.

The point being made here, according to Okorosaye-Orubite, Paulley and Abraham (2012:266) is that the extent to which civilization can be sustained in any place is dependent on the extent the intellectual momentum and vigour is being sustained by the universities. Nigeria as an emerging economy is desirous of having graduates as products of her universities endued with the relevant quality to drive a modern and vibrant economy in a highly competitive global setting more so with several policies in place driving the aspiration including Vision 20:2020 in focus. To drive home this Vision, the Federal Republic of Nigeria (FRN, 2014:39-40) gave Nigerian universities ((and other tertiary institutions) the tasks of, among others,

1) contributing to national development through high level relevant manpower training;

2) developing to the intellectual capability of the individual to understand and appreciate the local and external environments;

3) facilitating the acquisition of both physical and intellectual skills which will enable individuals to be self reliant and become useful members of the society; and

4) promoting national unity and international understanding.

Through this medium, it is hoped that the expectations of the government and people of Nigeria for the production of highly-skilled entrepreneurial graduates, research outputs that will provide solutions to both national and global challenges and production of professional and technical services for both the local, national and the global communities will be met. These goals will enhance the development of the Nigerian society and so they should be supported by successive governments.

From the above, the university is more or less an industrial establishment for turning out the most precious products-the accomplished individuals. It is thus an agent for shaping not only the destiny of man but also of the state. This way, the world is made a better place to live in.

The university is a community of scholars, which believes in the superiority of the mind over matter and insists that everything material should be subordinated to the intellect. It is, therefore, a place where concepts hallowed by age and tradition are subjected to severe scrutiny and knowledge grows through dissent, not through compromise.

In every country, machineries are put in place to ensure that the education provided by the universities is of good quality. To guarantee this quality, minimum standards are set in the areas of academic programmes and personnel and all universities in a particular country are expected to meet those standards. Appropriate financial provision (funding) is also generally made to help the universities meet those standards. This is what quality assurance is all about. This paper examines the issues relating to quality assurance in Nigerian universities and the paradox in this direction, using the National Universities' Commission (NUC), as an agency of the Federal Government saddled with the responsibility for ensuring quality assurance in the universities, as a case study. These are the issues the paper will be contending with.

\section{Quality in Education}

Quality has to do with something special or that which distinguishes a person or thing. It is an assurance that a product meets a given standard during the process of manufacturing so as to meet the customers' satisfaction. Ekundayo (2011:101), citing Harvey and Green (1993), identified the 
commonly used definitions of quality as exceptional or excellence, perfection or consistency, fitness for purpose, value for money, relevance and worthiness, standard, efficiency, among others.

Quality as applied to education, according to Anikweze (2010:210-211), is an education that is relevant to the developmental needs of the recipients as individuals and to the society in which the individuals live and operate. Citing UNESCO (2000), Anikweze (2010:211) said quality education is locally relevant and culturally appropriate. It is informed by the past and relevant to the present, and prepares individuals for the future. Education teaches people to be better individuals, family members, community members and citizens. In other words, quality education should, yield outputs that are intellectually perspicacious, socially adaptable and miscible, vocationally skilled and competent, and morally sound.

Over the years, employers of labour and the general public have expressed concern over the quality of graduates from the Nigerian universities. Even for further studies outside the country for which, ordinarily, the graduates were to be admitted, due to the issue of quality of outputs, Nigerian graduates are subjected to qualifying examinations. The state of university education in Nigeria can, therefore, be described as one of massive explosion in students' enrolment and increasing number of prospective new entrants in the face of inadequate and obsolete infrastructure and equipment, inadequate academic staff in numbers and quality, and lack of relevance of academic programmes, resulting in the provision of low quality graduates. That the Nigerian education system does not appeal to foreign students is no news as no Nigerian university was ranked among the best five hundred (500) in the world (Daily Sun Newspaper: October 7, 2016:15). These are signs of vote of no confidence being passed on the country's education system. [All these raise the fundamental question of quality assurance in the academic programmes of Nigerian universities.

\section{Quality Assurance in Education}

Quality assurance, in relation to education, according to Materu (2007:3), is a planned and systematic review process of an institution or programmes to determine whether or not acceptable standards of education, scholarship, and infrastructure are being met, maintained and enhanced. It is a proactive means of ensuring quality in an organization, here the university, so that its products will conform to the expected standards. The essence is to ensure that expectations of the user of the manpower in relation to the quality of skills acquired by the product displayed is being met. It is aimed at, among other things, preventing quality challenges. A tertiary institution (university) is only as good as the quality of its teaching staff as they are the heart of the institution that produces its graduates, its research products, and its service to the institution, community and nation.

Quality in Nigerian university education is, however, a multi-dimensional concept that should embrace all its functions and activities; teaching and academic programmes, research and scholarship, staffing, students, buildings, facilities, equipment, service to the community and the academic environment (UNESCO, 1998).

For Okebukola (2004), quality assurance in Nigerian universities is a continuous process of improvement in the quality of teaching and learning activities that will be achieved through employing mechanisms that are internal and external to the universities. The internal mechanism has to do with instruments put in place by the institutions to ensure quality, while the external mechanism, which is the focus of this work, has to do with the activities of a regulatory body, in this 
context the National Universities Commission (NUC), to maintain the required quality. In both ways, it is aimed at assurance that the Minimum Academic Standards (MAS) are attained, maintained and enhanced.

The history of quality assurance in higher education in Africa goes back to the founding of the first universities in Africa (for example, Fourah Bay College in Sierra Leone in 1827), all of which were affiliated to partner universities located in the colonizing countries (the United Kingdom, France, and Portugal). The University of Dakar, now Cheikh Anta Diop University in Senegal, was regarded as an integral part of the French higher education system as late as the 1960s. Authority over the quality of university education in those early days was a function of their governing boards and faculty. With affiliation, the institutions automatically became part of the British, French, Portuguese or other systems of quality assurance through their partner universities. These institutions were subject to the same kinds of quality control as were in British or other European universities, including external examiners and other aspects of these systems.

\section{Why Quality Assurance in Nigeria's University Education?}

Labour market report on the prospect of Nigerian graduates by Oni and Dabalen (2000) shows that employers complained that graduates are poorly prepared for work. The report affirmed that quality academic standards have fallen drastically over the past decade and that a university degree is no longer a guarantee of communication skills and technical competence. As a result of this, Nigerian graduates are viewed as half-baked and ill-equipped for the labour market. In fact, the quality of university education in Nigeria has reduced considerably. The provision of adequate human and material resources promotes and enhances the quality of education in universities where these are not available, there is a fall in quality leading to a fall in the overall quality of education and the quality of products, in effect, the expected minimum standard set by the supervisory body (NUC) in the case of Nigeria) is not met.

A study in this connection was carried out by the NUC in 2004 (NUC:2004) on the performances of graduate teachers in the country. The study revealed that graduates in education were found to be incompetent in the teaching of a large number of subjects. In addition, the study revealed that most of them lacked practical as well as computer skills, displayed poor classroom management and control skills, and were unable to communicate effectively. Further, graduate teachers were found to exhibit difficulty in teaching a large number of topics in secondary school subjects such as English Language, Biology, Chemistry and Physics. It also went on to show that new graduate teachers lacked competences in the teaching of many topics in a variety of school subjects and in many skills such as improvisation, use of teaching aids, laboratory and equipment. This condition has not changed for the better as the report of The Times Higher Education (THE) global ranking of higher education in 2016/2017 only named the premier university in Nigeria, University of Ibadan as the $600^{\text {th }}$ best university in the world, among 1000 universities sampled for the study (Daily Sun : October 7, 2016:15). The ranking was based on teaching, research, citations of scholarly publications, industry, income and international outlook, amongst other parameters as critical responsibilities of universities globally. While this is the lot of the universities in Nigeria, which prides itself as the 'giant of Africa', some smaller and less endowed African countries such as South Africa, Egypt, Kenya, Ghana and Uganda have at least one of their universities making the global elite 
universities list ahead of Nigeria's best. South Africa, for example, had three of its institutions, namely University of Cape Town, Stellenbosch University and University of KwaZulu Natal all ranked ahead of University of Ibadan as they occupied the $148^{\text {th }}, 401^{\text {st }}$ and $501^{\text {st }}$ positions respectively in the said study.

While this is so in the Nigerian context, every state in the world and its university education graduates are meant to compete in an environment shaped by their own local and national needs as well as international expectations and standards. With globalization, the impacts of international standards are increasing and public demand for transparency and accountability is on the rise. Educators and policymakers are, therefore, challenged to set appropriate standards of their own, which draw on and reflect on the unique history, needs and expectations of their stakeholders. Furthermore, they are expected to put in place mechanisms to enforce standards and to monitor performance of their university education system, with a view to taking appropriate and timely measures to adapt to new realities. The main factors, according to Materu (2007:9-13), that drive the push to strengthen quality assurance in university education are among others, the

1) increased demand for university education and rising private contributions;

2) rapid growth of tertiary (university) enrollment in Nigeria without a matching increase in funding;

3) demands for increased transparency and accountability on the part of contributors/recipients of university education in the country;

4) need for reforms in university education to address new challenges;

5) new methods of delivery challenge to traditional approaches to university education development; and

6) the needs for quality higher education to improve retention of skilled human capital.

It is for these reasons that various countries have set up regulatory bodies to assure the quality of their university products. In India, for example, the National Assessment and Accreditation Council (NAAC) ensures this for entire country. Quality Assurance Agency for Higher Education is responsible for this assignment in the United Kingdom while the United States of America relies on Private Accreditation team for quality assurance in its higher institutions. In Nigeria, the Federal Government (FRN:2014:67), had stated that to ensure quality in education "government shall establish efficient and effective quality assurance agencies at federal, state, FCT and local government levels for monitoring and maintaining set standards at all levels of education...." The goals of these agencies according to FRN (2014:67-68) are to

1) set, maintain and improve standards in all aspects of the schools system;

2) ensure minimum standards and quality assurance of instructional activities in schools through regular inspection and continuous supervision;

3) disseminate on a regular basis, information on problems and difficulties of teachers and institutions and offer practical solutions to them; and

4) encourage dissemination of information on innovative and progressive educational principles and practices in the school system through publications, workshops, meetings, seminars, conferences, etc. 
At the university level in Nigeria, this responsibility, is bestowed on the National Universities Commission (NUC) for all universities irrespective, of whether the ownership status is that of the federal, state or private.

\section{National Universities' Commission (NUC) and Quality Assurance in Nigeria's University Education}

The National Universities Commission (NUC) in Nigeria is an agency of the Federal Government set up in 1962. It was situated in the Cabinet Office, Lagos, to oversee the development of universities in Nigeria. It became a statutory entity in 1974. The body has a statutory mandate to ensure quality university education in the country through the setting of minimum academic standard in all Nigerian universities' academic programmes. Minimum Academic Standard (MAS) is defined by Nwana (2008:1) as "the least level of performance expected of those being taught, as dictated by competent authorities in the discipline". Standards are prescribed set of realistic conditions that should be satisfied for a certain level of output to be attained. The benchmark specifications are well set out in the MAS documents and NUC embarks on accreditation exercise to ensure complete compliance with these standards by individual universities. It was Decree No 16 of 1985 that gave the NUC the statutory power to stipulate these minimum academic standards for all universities in the country and by 1989, the NUC made the first attempt at setting minimum standards for all undergraduate programmes in Nigerian universities.

The resultant effect was the publication of a document known as Minimum Academic Standards (MAS). This document (NUC:2002) provides for minimum floor space for lecture, laboratory facilities for student, minimum laboratory space, library space and holdings, minimum staff/student ratio for effective teaching and learning in any discipline, curriculum, minimum entry and graduation requirements for each discipline. This document became the first attempt at homegrown quality assurance. It is pertinent to note here that the issue of quality assurance in Nigerian university system pre-dates the establishment of NUC as the University of London, through its internal autonomous quality assurance mechanism, assured the quality of teaching and learning at the University College, Ibadan, just as it did for all its academic programmes in the University of London, to which the college was affiliated. This power ceased following the promulgation of Decree No 16 of 1985.

\section{Functions of NUC}

According to Okojie (2011:104-106), NUC as a way of ensuring the orderly development of university education in Nigeria performs the following functions among others. To

1) advise the president, state governors and private proprietors, through the minister, on the creation and location of new universities and other degree-awarding institutions in Nigeria as and when considered necessary, and in accordance with the commission's guidelines;

2) prepare, after consultation with all the state governments, the universities, the National Manpower Board and such other bodies as it considers appropriate, periodic master plans for the balanced and co-ordinated development of all universities in Nigeria;

3) lay down minimum standards for all universities in the Federal Republic of Nigeria and to accredit their degrees and other academic awards; 
4) ensure that quality is maintained within the academic programmes of the Nigerian universities;

5) be the regulatory agency responsible for the work related to the proper conduct of the affairs of universities;

6) recommend the establishment of new faculties or postgraduate studies in existing universities in the country; and

7) carry out such other activities as are conducive to the discharge of its functions.

\section{NUC Quality Assurance Processes in Nigeria's University Education}

Specifically with reference to quality assurance in Nigeria universities, NUC through the instrumentality of Decree No 1 of 1974 (NUC:2002) has the mandate to:

1) Assess institutions and/or programs;

2) Approve new academic programs/courses;

3) Advise the government on the approval of new higher education institutions;

4) Set minimum academic standards;

5) Rank institutions;

6) External examiners Monitor annual performance of the universities;

7) Approve foreign institutions;

8) Recognize degrees and equivalence;

9) Standardize academic designations and titles; and

10) Monitor part-time staff levels among others.

In carrying out the above mandate, the NUC involves itself in the following processes

1) peer reviews

2) institutional self assessment

3) site visit

4) writing of reports; and

5) accreditation of academic programmes.

According to NUC (2010), with specific reference to accreditation of academic programmes in the Nigeria universities system, it is done to ensure that at least the provisions of the Minimum Academic Standards (MAS) documents are attained, maintained and enhanced; assure employers of labour that Nigeria graduates have competences in their area of specialization; and certify to the international community that Nigerian universities are of high standard and that their graduates are adequately equipped for employment and for further studies.

\section{Stages of Accreditation}

Accreditation according to the NUC (Amendment) Decree No 49 of $22^{\text {nd }}$ December, 1988 means:

a system for recognizing educational institutions and programme offered in these institutions for a level of importance, integrity and quality which entitles them to the confidence of the educational community, the public they serve and employers of labour. 
There are three major aspects of accreditation exercises in which NUC is engaged in to assure quality of products of the universities in the country. These are pre-accreditation, accreditation; and postaccreditation visits

Pre-Accreditation Visit is primarily undertaken for resource verification which accounts for the readiness of any intended programme to be accredited. It is like mock accreditation to trial test the programme for use and for final presentation for full blown accreditation after two years. Resource verification is often carried out by assigned regulatory agencies.

Accreditation Visit is a situation in which professionals in academics are drawn from various higher institutions and professional bodies to serve as peer review panelists to carry thorough scrutiny of claims made by departments about the appropriate running of academic programmes in their institutions. The approved Minimum Academic Standards (MAS) are used as criteria for measuring quality compliance.

Post Accreditation Visit is a follow up monitoring visit, often by regulatory agency staff to ensure that the claims made during peer-review accreditation visit were not dismantled or discarded thereafter. All these mechanisms are strictly applied to ensure quality in the country's university education sub sector.

\section{Criteria Used by NUC in Accreditation to Assure Quality in Nigeria's Universities}

The NUC Manual of Accreditation Procedures, as quoted by Lassa (1992:85-86) provides the following criteria, among others, for accrediting degree progammes in Nigeria universities. These include

1) philosophy, mission, purpose, objectives and content of academic programme in terms of clarity and attainability;

2) curriculum, in terms of adequacy and appropriateness for the level of students in the particular field;

3) quantity and quality of teaching staff;

4) students' admission, retention, resources, learning and graduation;

5) standards of degree examination- the rules and regulations governing degree examinations and awards, the methods of assessment and the grading system;

6) financial support adequacy for departmental programmes;

7) physical and technological facilities; including library and information resources;- their availability in adequate numbers and functionality;

8) administration of department; and

9) employers' rating.

For each of these criteria, the NUC Memo (2006) gave the following maximum percentage score

- Staffing $32 \%$

- Academic Content 23\%

- Physical Facilities $25 \%$

- Library $12 \%$

- Funding 05\%

- Employer Rating 03\%

Total $\quad 100 \%$

Source: NUC: 2007 
Usually, the NUC makes use of ad-hoc accreditation teams drawn from experts and academics in the universities, ministries, professional organizations and industries. The team carries out a rigorous evaluation of any programme to be accredited in any university, using the above criteria as instruments for assessment using the standard questionnaires and observation guidelines produced by the NUC. The task of the team is to confirm the agreement or otherwise between what obtains in the university visited and the established Minimum Standards for the programme being accredited. The exercise usually ends with a brief dialogue on the findings between the team and the university officials.

The accreditation team submits its report to NUC which, based on the findings, may decide to accord the programme any of the following status.

\section{Full Accreditation Status}

Using the above criteria to earn full accreditation status, university programmes for evaluation must have a total score of $70 \%$ or above in addition to scoring at least $70 \%$ in each of the four core areas of staffing, academic content, physical facilities, and library. Full accreditation status lasts for six academic years, subject to a mid-term appraisal every three years. Full accreditation suggests the attainment of a satisfactory quality.

Interim Accreditation Status

An interim or conditional accreditation status is given when a programme scores between $60 \%$ and $69 \%$. This presupposes that the programme has some minor deficiencies that could be rectified in less than two academic years.

\section{Denied Accreditation}

If a programme, scores less than $60 \%$, it is denied accreditation. This means that the programme has serious shortcomings that can jeopardize the quality of instruction and of its graduates. Programmes that are denied accreditation have lost credibility and are assumed to be suspended and so cannot admit students. The university could apply for a re-visitation when the identified deficiencies have been rectified.

Apart from the accreditation exercises, the reports of occasional visitation panels to universities, according to Lassa (1992:85), yield evidences of quality control for university education in Nigeria. With these in place, the first accreditation exercise in the Nigerian University system was conducted in 1990 and was wrapped up in 1991 and ever since it has been on as an annual activity of the NUC in Nigerian universities to assure quality of university academic programmes.

While these are put in place to assure quality in the products of the universities externally by the NUC, Olatunbosun (2007:340) and Okojie (2009:37) had argued that internal mechanisms should be put in place to complement the efforts of the external body. This unit should be set up by each university management to monitor and evaluate academic programmes, especially the teaching and learning process. Essentially, the unit should be responsible for the

1) supervision of curriculum design, content and implementation;

2) supervision of instruction;

3) external examination system;

4) internal assessment for approval of new programmes;

5) monitoring of students' progression and achievement; 
6) periodic assessment of human and material resources available for each programme;

7) organizing workshops and seminars for academics; and

8) monitoring input, process and output of the system.

The unit should be responsible to the Senate of the university and should be made to work hand in hand with the Academic Planning Division and Curriculum Committee of the university concerned to evaluate academic programmes to ensure that they are in line with international standards.

\section{The Paradox}

While the concern for quality assurance in Nigerian university education, as portrayed above, is commendable and most desirable, the university system in the country is being plagued with many problems that make it difficult for the country's universities to compete favourably in the global economy. These challenges, in the opinion of this author, are the makings of the same institution (the government) that set up the NUC to assure standards. This is the paradox. It is centered majorly on:

\section{Inadequate Funding}

Of all the challenges facing Nigeria education, more so at the university level, the challenge of funding appears to be the most potent. Putting this in global perspective, Combs (1968:45) had posited that money is absolutely crucial input of any education system. It provides the essential purchasing power with which education acquires its human and material inputs. With too little money, education can be helpless. With ample supply, its problems become more manageable even though they do not vanish.

Accordingly, adequate funding and timely release of financial allocations to institutions of higher education constitute a formidable determinant of educational quality. This is so because a cursory look at the parameters for accreditation of programmes of Nigerian universities by the NUC for the assurance of quality are all revolving around the issue of funding. This bit was vividly captured by a one-time Executive Secretary of NUC, Professor Idris A. Abdulkadir, in his keynote address to the Nigeria Academy of Education, the highest professional body in the country in the realm of educational matters, in 1988 when he opined that

the issue of quality of education does not stop on setting up a minimum academic standards and setting up a high entry admission requirements and high cut off points in the Joint Matriculation Examinations (JME) but also on improving the conditions under which the students both in and outside the classroom are made to learn. It is true that as part of the minimum academic standards, the facilities by ways of available floor space per student, equipment, laboratory reagents, auto-tutorial facilities and optimum staff student ratio must be met, but by the same token, some efforts must be made by...government...in funding higher education (1991:169-170). 
This is the path, that the United States of America (USA), as a developed country, followed to enhance the quality of its education generally and higher education in particular following the severe challenge it received from the Soviet space exploits when former Soviet Union launched its first Satellite Sputink 1 into orbit in 1957. Following this challenge, some American educational revolutionists charged that American schools were more interested in social than intellectual development. Such charges and other criticisms inspired studies by the Rockefeller Brothers Fund on Education and by James B. Canant, President of Harvard University. Their findings, which were reported in "The Pursuit of Excellence" (1959) and the American High School (1959), focused attention on the teaching of science and mathematics, the problems of gifted students and the patterns of school support. Meanwhile, the American Government passed the National Defence Education Act (NDEA) of 1958, which provided for massive financial support for programmes and increased courses in science and mathematics. The impact this revolutionary sensitivity made on the American Higher Education curriculum, through adequate funding by its government, is what has brought about the present supremacy of the Americans in space power. This is not the case in Nigeria as the government has not considered it appropriate to do the same to education by way of adequate funding.

The historical background of the Nigerian universities makes them absolutely dependent on government for their financial requirements. This has placed a serious limitation to their quality assurance drive for the expectation of the end users of the university products for which the accreditation exercises are carried out. This is because the expanding financial burden of operating the university to ensure quality assurance is becoming increasingly difficult due to dwindling finances to the universities particularly the publicly-owned ones whose proprietorship resides within the same government responsible for these accreditation visits which is the paradox. In other words, quality cannot be sustained in the face of under-funding the universities are experiencing in recent time.

For instance, quality staffing (32\%), quality academic content (23\%), quality physical facilities $(25 \%)$, library facilities (12\%) that will meet the needs of globalised community, funding (05\%) and favourable employer rating $(03 \%)$ resulting in a hundred percent status of a university programme are all the products of adequate funding, which must come majorly from the proprietor of the universities, in this context the government, since the public universities in Nigeria are owned by the government.

For the universities to fulfill this mandate, they ought to be funded adequately. Sadly in Nigeria over the years, commitment to adequate funding of the sector has been a major issue which in a way has eroded the much needed autonomy of the universities and by extension has compromised standards, leading to poor global rating of the country's university academic programmes. Education generally is a basic social welfare service that any responsive government must provide her citizens. University education is a huge venture that demands government's wholehearted intervention and active participation due to its place in the development of manpower in any country.

In spite the above role the universities are saddled to play to enhance development, which is premised on adequate funding, a careful examination of the patterns of funding of education in the country shows that the contrary's educational system generally and university education as a sub set of the whole is grossly inadequate. The table below vividly buttresses the point being made. 
INTERNATIONAL JOURNAL OF ACADEMIC RESEARCH IN BUSINESS AND SOCIAL SCIENCES

Vol. 9, No. 3, March, 2019, E-ISSN: 222 2-6990 @ 2019 HRMARS

Table1: Federal Government Budgetary Allocation to Education Sector of Nigeria's Economy (1960-2016)

\begin{tabular}{lccccc}
\hline Year & \% Allocation & Year & \% Allocation & Year & \% Allocation \\
1960 & 6.02 & 1979 & 3.70 & 1998 & 10.27 \\
1961 & 6.15 & 1980 & 4.95 & 1999 & 11.12 \\
1962 & 5.19 & 1981 & 6.45 & 2000 & 8.36 \\
1963 & 3.43 & 1982 & 8.09 & 2001 & 7.00 \\
1964 & 3.65 & 1983 & 4.04 & 2002 & 5.9 \\
1965 & 3.57 & 1984 & 4.49 & 2003 & 1.83 \\
1966 & 4.23 & 1985 & 3.79 & 2004 & 10.5 \\
1967 & 4.88 & 1986 & 2.69 & 2005 & 9.3 \\
1968 & 2.84 & 1987 & 1.93 & 2006 & 11.00 \\
1969 & 2.20 & 1988 & 2.40 & 2007 & 8.09 \\
1970 & 0.69 & 1989 & 3.55 & 2008 & 13.0 \\
1971 & 0.53 & 1990 & 2.83 & 2009 & 6.54 \\
1972 & 0.62 & 1991 & 1.09 & 2010 & 6.40 \\
1973 & 0.88 & 1992 & 3.86 & 2011 & 1.69 \\
1974 & 2.96 & 1993 & 5.62 & 2012 & 10.0 \\
1975 & 4.57 & 1994 & 7.13 & 2013 & 8.70 \\
1976 & 8.71 & 1995 & 7.20 & 2014 & 10.63 \\
1977 & 3.12 & 1996 & 12.32 & 2015 & 4.06 \\
1978 & 11.44 & 1997 & 17.59 & 2016 & 6.08 \\
\hline
\end{tabular}

Source: Budget Office of the Federation, Ministry of Budget and National

Planning/www.yourbudgit.com

The Table above shows that funding of the Nigerian educational system from 1960-2016 has been haphazard. The year 1971 has the lowest (0.53\%) budgetary allocation, while the highest allocation (17.59\%) of funds was in 1997. Thus, in the fifty six (56) years (1960-2016) captured in this study, Nigeria has not performed to the expectation of the people in terms of education funding in the country, as the Federal Government has not allocated more than $17.59 \%$ of her annual budget to education.

For instance, in spite of the bulk of revenue at her disposal, the country has not met the $26 \%$ benchmark of annual allocation of funds to education as recommended for developing countries by the United Nations Educational, Scientific and Cultural Organization (UNESCO). Instead of striving to achieve that minimum recommendation, the funding of education is decreasing which has resulted in poor infrastructural development in public tertiary institutions in the country. Ironically this directive of UNESCO in principle, according to Newswatch (1999:24), has the blessings of the Nigerian Government as both the Vision 2010 Committee's Report of the Abacha's government. The Etsu Nupe Panel set up by the Federal Government of Nigeria also recommended same percentage to education in the country's annual budgetary provisions to enable education play its developmental role in the country. The implementation of this to make education play this role is, therefore, one of the core challenges facing the country. 
The situation in the states is even reverse, since education in the country is in the concurrent list of the constitution, as almost all of them are religiously following the template provided for them by the Federal Government in the funding of university education, more so with the excuse of recession. While this is so, another irony in the country is the establishment of many more universities in recent time as a way to shore up the political egos of the leaders or what Kosemani (1985) called 'geopolitical balancing in the country in the area of provision of university education'. In buttressing this assertion, Tell Magazine (2008:32), writes that with the exception of Kano and Yobe States, which allocated $18 \%$ and $26 \%$ of their entire budgets in 2008 respectively to education, all other states followed the pattern set for them by the Federal Government over the years. Ekiti State, as one of the educationally advantaged states in the country, for instance, allocated only $9.7 \%$ of its 2008 budget to education. Bayelsa State, as an oil rich state with its relatively high Federal allocation, can afford to allocate a paltry 5.2\% of its 2008 budget to education with its heavy education deficit reflected in the many lacks in the sector. In 2009, the State education sector was allocated only $9.23 \%$ of the State budget, an improvement over the previous year one may say, but actual release to the sector that year was only 3.5\% (Bayelsa State of Nigeria Strategic Education Sector Plan: 2013-2022: Nov: 2012:37), which reveals serious underfunding of the sector. Even at this, much of what came to the sector was spent on recurrent expenditure- salaries and overheads. It has been observed that over the years even the little fund allocated for projects in the sector is not released as at when due. In the end, the education sector receives much less than what is appropriated for its capital expenditure, thereby making it difficult for education to perform its role of stimulating development in the state. Rivers State under Sir (Dr.) Peter Odili had in 2003, 2004 and 2005 according to the Interim Report of the State Implementation Committee on Education (2008), reported that the state government allocated $4.6 \%, 2.6 \%$, and $0.8 \%$ respectively of its state budget to education as against the UNESCO's prescription. This pattern has not changed for better; instead it is getting worse due to the value the political leadership of the various tiers of governments in the country has placed on education.

The above sorry state of funding of education by the few states listed above is a reflection of what goes on in most states of the federation. This pattern of funding education certainly cannot make the sector to be an engine room to stimulate development in the country as it has done for other countries of the world that have genuine commitment to the education sector through adequate funding. Accordingly, the universities in the country which had hitherto competed favourably with similar institutions all over the world have nose-dived to a very pitiable situation due to poor funding. While this report is highly regrettable, the country cannot afford to compromise the standard of university education which is what the NUC accreditation exercise is to ensure such that universities in the country meet minimum standards that are consistent with the global goals of tertiary education. Universities are so called because those who pass through their portals should show evidence of learning and character commensurate with that level of education.

Paulley (2009:239) had argued that how much of the state fund education gets annually is usually a function of the vision and political will of the leadership of a given state. A political leadership that has placed high premium on the surrender value of education, particularly university education, will allocate what education deserves for it to execute its assigned role for the development of the society. For instance, even among developing countries, the funding of 
education is taken more seriously in countries whose leadership has placed a high premium on education.

This is what, as reported by National Freedom (January, 2005:4), Kpolovie and Obilor (2013: 283), we find in Morocco, where the government spends $26.1 \%$ on education; in Cote $D^{\prime}$ Ivoire it is 30\%; Uganda 27\%; Botswana 19\%; South Africa 25.8\%; Swaziland and Mexico 24.6 and 24.3 respectively; Tunisia and Lesotho each spend $17 \%$ of their funds on education; Burkina Faso $16.8 \%$; Togo 23.2\%; Kenya 22.5\%. Guinea 25.6\%, Malaysia 26.7\% and South Korea $22.4 \%$. These, according to Kpolovie and Obilor (2013:283-284), are the findings of the annual budgetary allocations to education of 20 World Bank sampled countries in 2012. Ghana, according to Tell Magazine (November 3, 2008:33), has been spending within the radius of $28 \%$ to $40 \%$ of its annual budget on education over the years. Ironically, Nigerians are sent to Malaysia, while others go to Ghana on their own, fellow third world countries, for training in technologically-based courses in recent times due to these countries' genuine commitment in terms of funding to education, which is missing in the case of Nigeria. This partially explains the frequent strike actions embarked upon by various operators of the education sector in the country such as the Nigerian Union of Teachers (NUT) and the Academic Staff Union of Universities (ASUU), among others, to bring to the front burner the rot in the system due to underfunding. For the business of accreditation to make meaning, the issue of funding by the proprietor of the public universities, being the government, as a social responsibility must be taken seriously so as to make the country's universities take their place in the league of elite universities in the world. This is important because many persons are priced out of the private universities due to the exorbitant fees charged by their proprietors as profit making motive appears to override the social service reason as business men/women, even though seriously speaking the standards cannot be ascertained in some of these universities. It is in fact the main reason for most crises in the university system in the country with the Academic Staff Union of Universities (ASUU) in Nigeria over the years.

\section{Conclusion and Way Forward}

The Federal Government that sets up NUC to, among others, assure quality of university academic programmes, should be faithful in the funding of education in the country as prescribed by UNESCO, more so as a member of the UNO. This is the path taken by other countries, including other developing countries in Africa, as shown. What this means is that government should first of all solve the challenge of inadequate funding of the universities in the country and all other things that will make the universities to provide the quality required by the NUC shall be added. This way the Nigerian universities as members of the global universities community, shall be competing favourably with their counterparts anywhere in the world.

The above suggestion is not unmindful of the position of the Federal Government through its National Policy on Education (FRN:2013) that funding of education is expensive and so cannot be sustained by the government alone. While this is correct and should be embraced by the universities and other stake holders in the sector, for the investors and private individuals to venture into the business of funding education generally and university education in particular, Obanya (2002:58) had admonished the Nigerian government that 
for the government to get the willing support of the...development partners (both internal and external) in the funding of ...education (as canvassed in the policy document) the government has to... demonstrate commitment...in concrete terms by going beyond rhetoric to positive action. The government has to put its house in order if it is going to mobilize even the Nigeria's internal resources...for funding of education adding that as long as ...it is seen as a source of patronage for party faithful, as long as most of the concrete activities are in the form of supplies and as long as 'contractocracy' continues to take prominence over the promotion of the goals of..., non-governmental financial resources will continue to elude the (education sector)

Accordingly, the government has to show genuine commitment in this direction before she can attract these bodies and individuals into the funding of the sector. With adequate funding, the ever increasing number of potential university students, the redefinition of the course contents to meet up with the reality of the changing time, distribution and method of delivery of academic programmes, which are imperative for the management of Nigerian universities, will be assured for the sustainable development of the university system in the country.

The Nigerian universities on their part, as a way of shoring up their dwindling allocation, coupled with recession, should look inward by intensifying other internal means of funding themselves, such as partnership with the private sector through endowment, from alumni associations, consultancy services, contract, research, sandwich and short vocational courses, staff schools among others. Ziderman and Albrecht (1985:103) and Wu: 1993, Tsang:1993), cited by Mgbodile (2001:51), have at different fora noted that universities in Senegal and Uganda generate about 4 to 5 percent of their annual expenditures through the renting out of facilities. In China, it is 12 percent of her higher education budget; 5 percent of Mongola budget and 14 percent of Vietnamese budget. Universities in Nigeria can borrow a leaf from these sources to make provision for quality in their academic programmes.

\section{References}

Abdulkadir, I.A. (1991). Keynote address. Paying for quality: The prospect. In R.O Ohuche (Ed). Moving education in Nigeria toward the year 2000. Enugu: Optimal Computer Solutions (Limited).

Anikieze, C.M. (2010). Access, quality and cost in education in Nigeria: Teacher production and issues of functional quality. In B.G Nworgu \& G.O Obioma (Eds). Universal basic education. Proceedings of the $24^{\text {th }}$ congress of the Nigerian Academy of Education, held at at the NCCE conference room, Abuja, from $2^{\text {nd }}-6^{\text {th }}$, November, 2009. Lagos: NERDC Press.

Bayelsa State of Nigeria (2012). Strategic education sector plan (SESP): 2013-2022. Yenagoa: Ministry of Education. 
INTERNATIONAL JOURNAL OF ACADEMIC RESEARCH IN BUSINESS AND SOCIAL SCIENCES

Vol. 9, No. 3, March, 2019, E-ISSN: 222 2-6990 ¿ 2019 HRMARS

Combs, P.H (196). The world education in crises: A system analysis. New York: Oxford University Press.

Dabalen, A. \& Oni, B. (2000). Labour market prospect for university graduates in Nigeria. Mimeograph report of World Bank/NISER.

Ekundayo, H.T. (2011). Accreditation and quality assurance in university education in Nigeria. In B.O Ogundele, O.A Moronkola \& J.F.Babalola (Eds). Contemporary Issues in education, health and sports: The way forward (A book of reading in honour of Prof J.A.Ajala). Ibadan: Department of human kinetics and health education, University of Ibadan.

Federal Government of Nigeria (2016). Budget Office of the Federation, Ministry of Budget and National Planning/www.yourbudgit.com

Kpolovie, P.J \& Obilor, I.E. (2013). Education funding in Nigeria: Adequacyinadequacy? In journal of education in developing areas (JEDA) 21(1) March. A journal of the faculty of education, University of Port Harcourt, pp 276-294.

Lassa, P.N. (1992). Maintaining quality in higher education in Nigeria. In B. Ipaye (Ed). Education in Nigeria: Past, present and future: (A book in honour of Professor Aliu Babatunde Fafunwa) Vol.1. Lagos: Macmillan Nigeria Publisher Ltd.

Materu, P. (2007). Higher education quality assurance in sub-saharan Africa: Status, challenges, opportunities and promising practices. Washington, D.C. World Bank Publication.

Mgbodile, T.O. (2001). Strategic planning for salvaging the university system in its financial crises. In A.U Akubue \& D. Enyi (Eds). Crises and challenges in higher education in developing countries. A book of readings. Ibadan: Wisdom Publishers Ltd.

National Freedom (2005). Education: The many lies of the 2005 budget. Kaduna: Freedom Global Network.

National Universities Commission (NUC) (2002). Quality assurance in Nigerian universities vol.1. Abuja: NUC.

Newswatch (1999). $1^{\text {st }} 100$ days: educational and health: So far so silent. September 13. Lagos Communication Limited. 30(10).

NUC (2004). Labour market expectations of Nigerian graduates. Abuja: NUC.

NUC (2007). Benchmark minimum academic standards for undergraduate programmes in Nigerian universities. Abuja. NUC. 
Nwana, O.C (2008). Standard in education: Capacity building and sustainable development in Nigeria. Keynote paper presented at the annual conference of the Faculty of Education, Nnamdi Azikiwe University, Awka. July 29 $9^{\text {th }}$ August, 2008.

Mgbodile, T.O (2001). Strategic planning for salvaging the university system in its financial crisis. In Akubue, A.U \& Enyi, D (Eds). Crises and challenges in higher education in developing countries. $A$ book of readings. Ibadan: Wisdom Publishers Ltd.

Obanya, P. (2002). Revitalizing education in Africa. Ibadan: Stirling Horden Pub. Nigeria.

Obeoegbulem, A.I. (2001). Financing higher education in Nigeria: Crisis and challenges. In Akubue, A.U \& Enyi, D (Eds). Crises and challenges in higher education in developing countries. A book of readings. Ibadan: Wisdom Publishers Ltd.

Okebukola, P. (2004). The state of universities in Nigeria, Abuja: NUC.

Okojie, J.A. (2009). Quality assurance in the Nigerian university system. The national scholar. A publication of the Academic Staff Union of Universities (ASUU) 6(1), Ibadan, pp 36-41.

Okojie, J.A. (2011). The roles and responsibilities of the national universities commission. In F.lyayi, E Oshio \& J.Okojie (Eds). Critical issues in university governance in Nigeria.Lagos: Malthouse Press Ltd.

Okorosaye-Orubite, A. K., Paulley, F.G \& Abraham, N.M. (2012). University autonomy, academic freedom and Academic Staff Union of Universities' (ASUU) struggles in Nigeria: A historical perspective. In Asian Social Science 8(12). Published by Canadian Centre of Science and Education. Pp 265-275.

Olatunbosun, J.B. (2007). The need for quality assurance in university education in Nigeria. In J.B. Babalola, G.O. Akpa, A.O. Ayeni \& S.O. Adedeji. (Eds.). Access, equity and quality in higher education. NAEP Publication.

Paulley, F. G. (2009). The role of education in the realization of the MDGs in Nigeria. In African Journal of Historical Sciences in Education: 5 (1 \& 2), pp. 230-242.

Rivers State Government (2008) State interim report on the state implementation committee on education. Port Harcourt: Government Press.

Tell Magazine (2008) Education: Monument of decay. The way out. No. 44 Special Edition: Tell Communication. November. 3. 
INTERNATIONAL JOURNAL OF ACADEMIC RESEARCH IN BUSINESS AND SOCIAL SCIENCES

Vol. 9, No. 3, March, 2019, E-ISSN: 2222-6990 @ 2019 HRMARS

Ziderman, A. \& Albrecht (1995). Financing universities developing countries. London: Palmer press. 